\title{
An Investigation of Hoteliers' Attitudes toward the Use of Social Media as a Branding Tool
}

\author{
Mohamed A. Nassar ${ }^{1}$ \\ ${ }^{1}$ Department of Management and Marketing, School of Business, Gulf University for Science \& Technology, \\ West Mishref, Kuwait \\ Correspondence: Mohamed A. Nassar, Department of Management and Marketing, School of Business, Gulf \\ University for Science \& Technology, Mubarak Al-Abdullah Al-Jaber Area, Block 5, Al-Aqsa Mosque Road, \\ Building 1, West Mishref, Kuwait. E-mail: Nassar.m@gust.edu.kw
}

Received: May 14, 2012 Accepted: May 28, 2012 Online Published: July 25, 2012

doi:10.5539/ijms.v4n4p93 URL: http://dx.doi.org/10.5539/ijms.v4n4p93

\begin{abstract}
This study investigates how hoteliers view social media as a branding strategy and elucidates the motivational factors that determine the adoption of social media as a branding tool. It was based on a survey of 491 hotels from the USA, the UK, and Egypt that ranged from one-star to five-star hotels. Data on hotels' locations, grades, numbers of rooms, positions of respondents, usages and perceptions of social media, types of social media used by hoteliers, and perceptions were collected. A major finding of this paper is that higher grade hotels have a higher probability of using social media. Furthermore, the study reveals that hotels in the USA and the UK use social media more often compared with those in Egypt.
\end{abstract}

Keywords: social media, hotels, brand, business, marketing, branding strategy

\section{Introduction}

A business can survive in a highly competitive market only if it is able to stand out from the rest by providing unique and desirable products and services (Bridges et al., 2003). As well as being driven by continuous technological advancement and innovations, a new dimension in building the essence of business is to harness a firm's core values, solidify its reputation, and communicate its products and services in the marketplace through branding (Okapara, 2007).

Establishing a unique brand enables a company to not only improve its image, but also provide a personality to its business (Aaker, 2004). Imperatively, the objective of branding is to rediscover the core values of a business, displaying the exclusivity of the services that it offers, highlighting its uniqueness, and differentiating its products from those of its competitors (Aaker \& Jacobson, 2001). This involves every transaction between the firm and its suppliers and customers (Shocker et al., 1994; Aaker, 1991). Furthermore, branding highlights corporate identity, harnesses business productivity, and drives firms to operate profitably. Through branding, the quality and value of their services can be elevated above similar commodities in the market. Hotels have long used branding because of the advantages that a brand image can bring to their core services and operations (O’Neil \& Matilla, 2004; Jiang et al., 2002; O’Neill \& Lloyd-Jones, 2001; Whalen, 2010).

The exponential increase in the use of the Internet and its widespread applications has created online media, or social media (Jones, 2009; Williams, 2009; Ghali, 2011). Businesses are now taking advantage of introducing social media into their marketing programs (Falkow, 2009). Social media has many benefits for a business, including viral potential, cost, and the creation of brand reputation. The idea of marketing products using social media has increased, and this rise in usage has attracted many hotels to follow suit. Consequently, many hotels now view social media as essential for their future plans and they have already started designing strategies on how to implement it (Hasler, 2011; Noone et al., 2011; Kimes, 2000). Companies have even employed personnel to engage with customers online and maintain social media websites such as YouTube, Facebook, or Twitter. This activity allows businesses to stay in touch with their customers.

The aim of this study is to investigate the motivational factors that determine the adoption of social media as a branding tool. The specific objectives of the present study are to:

(i) Investigate how hotel managers view social media as a branding strategy. 
(ii) Identify the motivational factors behind hoteliers adopting social media to brand their services.

(iii) Survey how social media can help hotels brand their services.

\section{Literature Review}

Social media gives hotels the opportunity to merge these two antiquated strategies in a seamless and efficient manner (Lanz et al., 2010). Through new communication channels such as Twitter, which has users tweeting 27 million times a day, and Facebook, which has over 350 million users (Browser media, 2011), a hotel can now send out a mass message and can even receive immediate responses via the same channels. "While a business blog can certainly help you do the same, social media allows you to do so before a readymade niche audience and to build authority much faster within a larger established community while you build your own following on your own site" (Hessinger, 2011).

According to Aggarwal (2009), this is important because "Social Media allows you to establish a relationship with your customer like no other media has previously allowed. It enables you to establish a 1-1 relationship where you are getting regular feedback on how your customers are reacting to your marketing messages”.

Hotels are now able to immediately track public response to a sent message or receive feedback on the quality of their offers and rates. They can also test the perception of a new product along with its concept, partnership, or even hotel location.

Even more advantageous is that hotels no longer have to spend countless hours or dollars promoting their newest rates or special offers. For example, Joie De Vivre, a luxury hotel chain in California, uses such strategies to bolster its profits and connect with its customers. Owing to the nature of the social media landscape, individuals can now pass on any information. The followers of any particular customer, for example, can see his or her comments on Twitter or Facebook. In turn, the followers of that individual may comment on previous comments. This results in a ripple of information involving the hotel's original post without any follow-up effort from the hotel itself (Rao, 2010).

Furthermore, hotels can now cater more easily to their customers' needs. Offering reservations directly helps to keep the conversation between the hotel and its guests, using social media to communicate took the relationship beyond the booking transaction. The hotel can find out what pillow guests prefer, the drinks they want in the minibar or the type of room they need. Personalized service can keep a guest coming back, he said, and that, in turn, helps hotels hold the line on room prices” (Weed, 2011).

This encourages customers to register with social media websites directly rather than having to search for a specific website. Customers can also make specific arrangements or ask particular questions through social media sites, which allows for more efficient customer service.

According to the UK Search Engine Marketing Agency (2010), Twitter had 75 million user accounts and averaged 27 million tweets per day in 2010. This number has already grown to 175 million registered Twitter users, tweeting about 95 million tweets per day, thus representing an increase of 250\% (Browser Media, 2011). Facebook is another obvious front that hotels can take advantage of because of the grassroots campaigns that can be started through items such as the "Like" button.

With the loyalty created through perceived personalised interaction involving the "Like" button, which links individuals to the hotel's brand and current deals, the hotel can assure itself of a higher percentage of brand loyalty. "Hotels are using social media channels to engage with brands and seek out tribes of similar customers. These channels help to communicate further and better with existing customers and are also a powerful medium to attract new customers" (Severn, 2010).

Furthermore, social media allows hotels to access millions of users and gives them the platform to speak directly to individuals. Whether an individual has a query or wants to book a room, hotels can now accommodate customers' wishes - and all with the brand visible on their social media profiles. "Social media helps to develop and nurture 1-1 relationships where you get regular feedback on how customers are reacting to your marketing messages" (Grove, 2010).

After weathering the storm of low-cost travel sites, the hotel industry and individual hotels must now aim to re-establish their brands. This includes not sticking to one social media, but publicising themselves on all. Customers do not always show loyalty to a single media and often have multiple accounts, which they link together. This form of linkage provides businesses with the opportunity to spread information exponentially. As Aggarwal (2011) stated, "Flickr, Twitter and YouTube should be inter-linked to your Facebook account. 
Integrating and cross-linking the channels will help you in optimization, keeping it fresh as well as in expanding your network".

Although there are concerns about using social media because negative reviews can spread as quickly as do good reviews, it is important to remember that negative feedback offers an opportunity to improve. Lacy (2010) stated that, "Social media provides the opportunity to hotels to act quickly and be receptive. Focus should be placed on the positive reviews rather than deleting the negative ones". Hotels that encourage and respond to reviews can generate large responses. The basics of any business is receiving and responding to customer feedback in order to provide better service, and social media provides the opportunity to optimise the response tactic. Lacy (2010) continued, "Another advantage for hotels is their ability to have a heads up on what their competitors are doing".

Hotels can also provide award packages or special offers through social media in order to entice members and help spread knowledge of the brand. Two examples of using this social media strategy are Premier Inn and Wynn Hotel and Casino. Premier asked its customers to let others know about the wonderful locations where they were visiting.

Premier launched a trial of a Twitter concierge program. On Fridays, customers can send an inquiry to the concierge via Tweet using the hashtag \#PIconcierge. The hotel encouraged its customers to Tweet questions "on anything from local activities for the kids, karaoke bars in the area, directions to the local theatre or even where to find an emergency dentist.

Hyatt launched its Twitter Concierge service during a marketing campaign in May 2009. Hyatt hotels believe that this type of marketing ensured that customers would gain rewards directly through the social media source and would, in turn, lead others to use the media to seek the specific hotel and brand.

\section{Methodology}

This study used a descriptive approach to investigate how hoteliers view social media as a branding strategy and elucidate the motivational factors that determine the adoption of social media as a branding tool. The main aim of the descriptive approach is the exploration and clarification of phenomena where accurate information is lacking (Gay \& Airasian, 2000; Malhotra, 2012) and to present facts concerning the status of a situation or a condition, as it exists at the time of the study. It is a type of "conclusive research that has it major objective to description of something - usually market characteristics or functions" (Malhotra, 2012:104). Descriptive studies are based on the perceptions or reactions of respondents to the research questions. Such an approach aims to provide thorough descriptions, with a view to providing material and generating assumptions and targets for subsequent research, which is the case for this research.

The sampling frame included hotels in three major destinations Egypt (representing Africa), the USA (representing North America), and the UK (representing Europe). These three markets were selected for this study because they all have a large number of hotels and cover important tourism destinations. Sampled hotels ranged from one-star to five-star in the three destinations and data of hotels' locations, grades, numbers of rooms, websites, chain information, and contact information were collected. In total, 1665 hotels were included in the sample (720 hotels in the USA, 525 hotels in the UK, and 420 hotels in Egypt). The list of hotels was randomly drawn from many of the lists available online and included hotel directories, online guides, and hotel rating sites.

Data collection included two phases. In phase one, data were collected using a structured email survey in order to ease responses, not least because the study population was geographically dispersed. A questionnaire was sent via email to 954 hotels randomly selected from the database and 273 questionnaires were returned, which was a response rate of $28.6 \%$.

Phase two aimed to collect more responses to support the study's initial findings. A questionnaire was developed using Google documents and the link of the survey URL was emailed to respondents; two reminder emails were also sent to motivate more respondents to participate. During this phase, 711 emails were sent and 218 usable surveys were returned, which was a response rate of $30.6 \%$.

The questionnaire included three sections. The first section asked respondents to provide general data about their positions and hotels (location, number of rooms, and grade), which were then statistically tested for associations with their experiences of social media branding. Section two explored respondents' general understanding of branding using various social media tools and assessed their attitudes towards social media for public relations (PR), marketing, and branding. This section also included questions about hotel managers' perceptions of the advantages of social media branding. The final section of the questionnaire explored hoteliers' current and possible future intentions to apply social media branding. 
Responses were received from 491 hotels, giving an aggregate response rate of $\sim 30 \%$. Table 1 depicts the sample and its distribution across the three study destinations.

Table 1. Locations and grades of the surveyed hotels (percentage)

\begin{tabular}{|c|c|c|c|c|c|c|}
\hline \multirow[b]{2}{*}{ Location } & \multicolumn{6}{|c|}{ Hotel grade } \\
\hline & One-star & Two-star & Three-star & Four-star & Five-star & $\begin{array}{l}\text { Total } \\
\text { number of } \\
\text { hotels } \\
\text { surveyed }\end{array}$ \\
\hline USA & $\begin{array}{l}18 \\
(10.7 \%)\end{array}$ & $\begin{array}{l}33 \\
(19.6 \%)\end{array}$ & $\begin{array}{l}21 \\
(12.5 \%)\end{array}$ & $\begin{array}{l}43 \\
(25.6 \%)\end{array}$ & $\begin{array}{l}53 \\
(31.5 \%)\end{array}$ & 168 \\
\hline UK & $\begin{array}{l}14 \\
(8.8 \%)\end{array}$ & $\begin{array}{l}30 \\
(18.9 \%)\end{array}$ & $\begin{array}{l}32 \\
(20.1 \%)\end{array}$ & $\begin{array}{l}43 \\
(27.0 \%)\end{array}$ & $\begin{array}{l}40 \\
(25.2 \%)\end{array}$ & 159 \\
\hline Egypt & $\begin{array}{l}6 \\
(3.7 \%)\end{array}$ & $\begin{array}{l}20 \\
(12.2 \%)\end{array}$ & $\begin{array}{l}27 \\
(16.5 \%)\end{array}$ & $\begin{array}{l}51 \\
(31.1 \%)\end{array}$ & $\begin{array}{l}60 \\
(36.6 \%)\end{array}$ & 164 \\
\hline Total & $\begin{array}{l}38 \\
(7.7 \%)\end{array}$ & $\begin{array}{l}83 \\
(16.9 \%)\end{array}$ & $\begin{array}{l}80 \\
(16.3 \%)\end{array}$ & $\begin{array}{l}137 \\
(27.9 \%)\end{array}$ & $\begin{array}{l}153 \\
(31.2 \%)\end{array}$ & 491 \\
\hline
\end{tabular}

Data analysis was performed using SPSS 17 statistical software. To analyse the motivational factors behind using social media, a Logit model was developed. Logit models are generally used when research is interested in the probability of the occurrence of a particular event. The present study was conducted to ascertain whether hotel size, grade, and location influence the use of social media.

\section{Results and Discussion}

Table 1 depicts the grades and locations of the hotels surveyed. Of the 491 hotels responding, 168 hotels (34.2\%) were from the USA, 159 (32.4\%) from the UK, and 164 (33.4\%) from Egypt. The grade of hotels ranged from one-star to five-stars. In the USA, the majority (31.5\%) of hotels surveyed were five-star hotels followed by four-star (25.6\%) and two-star (19.6\%), while in the UK the majority of hotels surveyed were four-star (27\%) followed by five-star (25.5\%) and three-star (20.1\%). In Egypt, most surveyed hotels were five-star (36.6\%) followed by four-star (27.9\%) and three-star (16.3\%).

The surveyed hotels were divided into three categories according to number of rooms: (i) hotels with fewer than 50 rooms, (ii) hotels with 50-100 rooms, and (iii) hotels with more than 100 rooms. Of the hotels surveyed, $52.1 \%$ had more than 100 rooms, $29.5 \%$ had $50-100$ rooms, and $18.3 \%$ had fewer than 50 rooms. Across all grades of hotels, most had more than 100 rooms (Table 4). There were $10.3 \%$ and $31.7 \%$ one-star and four-star hotels, respectively with 50 to 100 rooms. By contrast, $18.8 \%, 16.8 \%$, and $32 \%$ of the two-star, three-star, and five-star hotels, respectively, had more than 100 rooms (Table 2). 
Table 2. Number of rooms by grade of the surveyed hotels

\begin{tabular}{|c|c|c|c|c|c|}
\hline \multirow{2}{*}{ Hotel grade } & \multirow[b]{2}{*}{ Description } & \multicolumn{4}{|c|}{ Number of rooms } \\
\hline & & $\begin{array}{l}\text { Under } \\
\mathbf{5 0}\end{array}$ & $\begin{array}{l}\text { 50-10 } \\
0 \\
\end{array}$ & $\begin{array}{l}\text { More than } \\
100\end{array}$ & Total \\
\hline \multirow{4}{*}{ One-star } & Number of observations & 8 & 15 & 15 & 38 \\
\hline & Percentage (total number of hotels in this grade) & 21. & 39.5 & 39.5 & 100 \\
\hline & Percentage (total number of hotels by hotel rooms) & 8.9 & 10.3 & 5.9 & 7.7 \\
\hline & Number of observation & 16 & 19 & 48 & 83 \\
\hline \multirow[t]{3}{*}{ Two-star } & Percentage (total number of hotels in this grade) & 19.3 & 22.9 & 57.8 & 100 \\
\hline & Percentage (total number of hotels by hotel rooms) & 17.8 & 13.1 & 18.8 & 16.9 \\
\hline & Number of observations & 15 & 22 & 43 & 80 \\
\hline \multirow[t]{3}{*}{ Three-star } & Percentage (total number of hotels in this grade) & 18.8 & 27.5 & 53.8 & 100 \\
\hline & Percentage (total number of hotels by hotel rooms) & 16.7 & 15.2 & 16.8 & 16.3 \\
\hline & Number of observation & 23 & 46 & 68 & 137 \\
\hline \multirow[t]{3}{*}{ Four-star } & Percentage (total number of hotels in this grade) & 16.8 & 33.6 & 49.6 & 100 \\
\hline & Percentage (total number of hotels by hotel rooms) & 25.6 & 31.7 & 26.6 & 27.9 \\
\hline & Number of observations & 28 & 43 & 82 & 153 \\
\hline \multirow[t]{4}{*}{ Five-star } & Percentage (total number of hotels in this grade) & 18.3 & 28.1 & 53.6 & 100 \\
\hline & Percentage (total number of hotels by hotel rooms) & 31.1 & 29.7 & 32.0 & 31.2 \\
\hline & Number of observations & 90 & 145 & 256 & 491 \\
\hline & Percentage (total number of hotels in this grade) & 18.3 & 29.5 & 52.1 & 100 \\
\hline Total & Percentage (total number of hotels by hotel rooms) & 100 & 100 & 100 & 100 \\
\hline
\end{tabular}

The positions of respondents included Managers, Assistant Managers, Directors, Senior Officers, and others. The respondent’s position was mostly Managers followed by others and Assistant Managers (Table 3).

Table 3. Positions of respondents included in the survey

\begin{tabular}{|c|c|c|c|c|c|c|}
\hline \multirow[t]{2}{*}{ Positions of respondents in the hotel } & \multicolumn{6}{|c|}{ Number of respondents by hotel grade } \\
\hline & One-star & Two-star & Three-star & Four-star & Five-star & Total \\
\hline Manager & 7 & 21 & 18 & 42 & 31 & 119 \\
\hline Assistant Manager & 5 & 14 & 21 & 30 & 39 & 109 \\
\hline Director & 11 & 14 & 9 & 21 & 32 & 87 \\
\hline Senior Officer & 5 & 14 & 12 & 21 & 22 & 74 \\
\hline Others & 10 & 20 & 20 & 23 & 29 & 102 \\
\hline Total & 38 & 83 & 80 & 137 & 153 & 491 \\
\hline
\end{tabular}

Across all grades of hotels, respondents were more often Managers for the two-star and four-star hotels, Assistant Managers for the three-star and five-star hotels, and Directors for the one-star hotels.

The usage of social media by grade, location, and size is shown in Table 4 . 
Table 4. Usage of social media by grade, location, and size of the surveyed hotels

\begin{tabular}{|c|c|c|c|c|}
\hline & & $\begin{array}{l}\text { Number of hotels that do } \\
\text { not use social media as part } \\
\text { of a branding strategy* }\end{array}$ & $\begin{array}{l}\text { Number of hotels that use } \\
\text { social media as part of a } \\
\text { branding strategy* }\end{array}$ & $\begin{array}{lr}\begin{array}{l}\text { Total } \\
\text { of number } \\
\text { surveyed }\end{array} \\
\end{array}$ \\
\hline \multirow{5}{*}{ Hotel grade } & One-star & $35(92.1)$ & $3(7.9)$ & 38 \\
\hline & Two-star & $67(80.7)$ & 16 (19.3) & 83 \\
\hline & Three-star & 37 (46.3) & 43 (53.8) & 80 \\
\hline & Four-star & 43 (31.4) & $94(68.6)$ & 137 \\
\hline & Five-star & 21 (13.7) & $132(86.3)$ & 153 \\
\hline \multirow{3}{*}{ Location } & USA & 63 (37.5) & $105(62.5)$ & 168 \\
\hline & UK & 57 (35.8) & $102(64.2)$ & 159 \\
\hline & Egypt & $83(50.6)$ & 81 (49.4) & 164 \\
\hline \multirow{3}{*}{$\begin{array}{l}\text { Hotel } \\
\text { Size }\end{array}$} & Under 50 & 33 (36.7) & 57 (63.3) & 90 \\
\hline & $50-100$ & $56(38.62)$ & $89(61.38)$ & 145 \\
\hline & More than 100 & $114(44.5)$ & $142(55.5)$ & 256 \\
\hline Total & & $203(41.3)$ & $288(58.7)$ & 491 \\
\hline
\end{tabular}

*Values within parentheses indicate the percentages

Of all the hotels surveyed, 58.7\% used social media as a branding strategy. Of the one-star and two-star hotels, $92.1 \%$ and $80.7 \%$, respectively, did not use social media as a branding strategy, whereas $46.3 \%$ of three-star hotels, $68.6 \%$ of four-star hotels, and $86.3 \%$ of five-star hotels used social media (Table 4). The results also show that $62.5 \%$ hotels in the USA and $64.2 \%$ in the UK used social media, whereas the number of Egyptian hotels using and not using social media were almost the same (Table 6). Medium-sized hotels with 50 to 100 rooms used social media more often than did small and big hotels (Table 4).

A more detailed analysis of social media usage is presented in Table 5.

Table 5. Usage of social media by location, grade, and size of hotels

\begin{tabular}{|c|c|c|c|c|c|c|}
\hline Location & Grade & Number of rooms & $\begin{array}{l}\text { Do not use social } \\
\text { media as part of a } \\
\text { branding strategy* }\end{array}$ & $\begin{array}{l}\text { Use social media as } \\
\text { part of a branding } \\
\text { strategy* }\end{array}$ & Total & \\
\hline & & Under 50 & $4(22.2)$ & $0(0.0)$ & 4 & \\
\hline & One-star & 50-100 & $6(33.3)$ & $0(0)$ & 6 & 18 \\
\hline & & More than 100 & $7(38.9)$ & $1(5.6)$ & 8 & \\
\hline & & Under 50 & $7(21.2)$ & $2(6.1)$ & 9 & \\
\hline & Two-star & 50-100 & $4(12.1)$ & $2(6.1)$ & 6 & 33 \\
\hline & & More than 100 & $16(48.5)$ & $2(6.1)$ & 18 & \\
\hline & & Under 50 & $0(0)$ & $0(0)$ & 0 & \\
\hline \multirow[t]{12}{*}{ USA } & Three-star & 50-100 & $1(4.8)$ & $5(23.8)$ & 6 & 21 \\
\hline & & More than 100 & $6(28.6)$ & 9 (42.9) & 15 & \\
\hline & & Under 50 & $0(0)$ & $3(7.0)$ & 3 & \\
\hline & Four-star & 50-100 & $3(6.98)$ & $13(30.23)$ & 16 & 43 \\
\hline & & More than 100 & $7(16.3)$ & 17 (39.5) & 24 & \\
\hline & & Under 50 & $1(1.9)$ & $9(17.0)$ & 10 & \\
\hline & Five-star & 50-100 & $0(0)$ & $9(17.0)$ & 9 & 53 \\
\hline & & More than 100 & $1(1.9)$ & $33(62.3)$ & 34 & \\
\hline & & Under 50 & $4(28.6)$ & $0(0)$ & 4 & \\
\hline & One-star & 50-100 & $5(35.7)$ & $1(7.1)$ & 6 & 14 \\
\hline & & More than 100 & $4(28.6)$ & $0(0)$ & 4 & \\
\hline & & Under 50 & $4(13.3)$ & $3(10)$ & 7 & \\
\hline \multirow{5}{*}{ UK } & Two-star & 50-100 & $7(23.3)$ & $1(3.3)$ & 8 & 30 \\
\hline & & More than 100 & $14(46.7)$ & $1(3.3)$ & 15 & \\
\hline & & Under 50 & $4(12.5)$ & $10(31.3)$ & 14 & \\
\hline & Three-star & 50-100 & $3(9.4)$ & $4(12.5)$ & 7 & 32 \\
\hline & & More than 100 & $7(21.9)$ & $4(12.5)$ & 11 & \\
\hline
\end{tabular}




\begin{tabular}{|c|c|c|c|c|c|c|}
\hline & & Under $\mathbf{5 0}$ & $4(9.3)$ & $12(27.9)$ & 16 & \\
\hline & \multirow[t]{3}{*}{ Four-star } & 50-100 & $0(0)$ & $11(25.6)$ & 11 & 43 \\
\hline & & More than 100 & $0(0)$ & $16(37.2)$ & 16 & \\
\hline & & Under 50 & $0(0)$ & $13(32.5)$ & 13 & \\
\hline & \multirow[t]{3}{*}{ Five-star } & 50-100 & $0(0)$ & $17(42.5)$ & 17 & 40 \\
\hline & & More than 100 & $1(2.5)$ & $9(22.5)$ & 10 & \\
\hline & & Under 50 & $0(0)$ & $0(0)$ & 0 & \\
\hline & \multirow[t]{3}{*}{ One-star } & 50-100 & $2(33.3)$ & $1(16.7)$ & 3 & 6 \\
\hline & & More than 100 & $3(50)$ & $0(0)$ & 3 & \\
\hline & & Under 50 & $0(0)$ & $0(0)$ & 0 & \\
\hline & \multirow[t]{3}{*}{ Two-star } & 50-100 & $4(20)$ & $1(5)$ & 5 & 20 \\
\hline & & More than 100 & $11(55)$ & $4(20)$ & 15 & \\
\hline & & Under 50 & $0(0)$ & $1(3.7)$ & 1 & \\
\hline \multirow[t]{8}{*}{ Egypt } & \multirow[t]{3}{*}{ Three-star } & 50-100 & $6(22.2)$ & $3(11.1)$ & 9 & 27 \\
\hline & & More than 100 & $10(37.0)$ & $7(25.9)$ & 17 & \\
\hline & & Under 50 & $1(2.0)$ & $3(5.9)$ & 4 & \\
\hline & \multirow[t]{3}{*}{ Four-star } & 50-100 & 11 (21.6) & $8(15.7)$ & 19 & 51 \\
\hline & & More than 100 & $17(33.3)$ & 11 (21.6) & 28 & \\
\hline & & Under 50 & $4(6.7)$ & $1(1.7)$ & 5 & \\
\hline & \multirow[t]{3}{*}{ Five-star } & 50-100 & $4(6.7)$ & $13(21.7)$ & 17 & 60 \\
\hline & & More than 100 & 10 (16.7) & 28 (46.7) & 38 & \\
\hline Total & & & 203 & 288 & 491 & \\
\hline
\end{tabular}

It presents the percentage of use and non-use of social media across three locations along with the grade and size of hotels. In the USA, one-star and two-star hotels did not use social media, while the usage of social media was common for three-star, four-star, and five-star hotels, irrespective of hotel size. Of all three-star hotels, 23.8\% with 50 to 100 rooms and $42.9 \%$ with more than 100 rooms used social media as a branding strategy. Among all four-star hotels, only $7 \%$ with fewer than 50 rooms, $30.2 \%$ with 50 to 100 rooms, and $39.5 \%$ with more than 100 rooms used social media. For five-star hotels, $17 \%$ of hotels with fewer than 50 and between 50 to 100 rooms used social media, whereas $62.3 \%$ of hotels with more than 100 rooms used social media (Table 5). Therefore, we can say that social media usage is common for the higher graded hotels in the USA.

In the UK, low graded hotels, in particular one-star and two-star hotels, used social media rarely. Altogether, $35.7 \%$ of all hotels that were one-star and had 50 to 100 rooms, and $46.7 \%$ of all hotels that were two-star and had more than 100 rooms did not use social media. The higher graded hotels, i.e., the four-star and five-star hotels, used social media as a branding strategy. Within all three-star hotels in the UK, $31.3 \%$ with fewer than 50 rooms and $12.5 \%$ with 50 to 100 rooms used social media, while $21.9 \%$ of hotels with more than 100 rooms did not. This finding is an exception, and could have been caused by a minor discrepancy in the sample framework. Altogether $90.7 \%$ of all four-star hotels and $97.5 \%$ of all five-star hotels in the UK used social media (Table 5). Therefore, it can be concluded that the higher graded hotels in the UK use social media as a branding strategy.

Egyptian hoteliers depict a totally different picture. Most hotels did not use social media as a branding strategy, with the exception of five-star hotels with 50 to 100 rooms and more than 100 rooms (Table 5). Only $16.7 \%$ of one-star hotels, $25 \%$ of two-star hotels, $40.7 \%$ of three-star hotels, and $43.1 \%$ of four-star hotels used social media, reflecting that the majority of hotels did not use social media. Among all five-star hotels in Egypt, $46.7 \%$ with more than 100 rooms used social media.

From this, a conclusion can be drawn that hotels in Egypt do not use social media. One of the reasons for this might be because of their low exposure to social media. It is self-explanatory that hotels with higher grades accommodate customers of higher class or economic status, who have better access to social media, and therefore these hotels use social media to target, access, and attract their customers.

In general, hotels in the USA and UK use social media more than hotels in Egypt do. In particular, higher grade hotels in the USA and UK make use of social media more than the lower grade hotels do. In general, hotels that have more rooms and higher grades are more acquainted with social media branding in all locations.

The perception about social media is presented in Tables 6 and 7 . 
Table 6. Social media is about marketing

\begin{tabular}{llllllll}
\hline & & Strongly Agree & Agree & $\begin{array}{l}\text { Neither Agree nor } \\
\text { Disagree }\end{array}$ & Disagree & $\begin{array}{l}\text { Strongly } \\
\text { Disagree }\end{array}$ & Total \\
\hline & One-star & $11(28.95)$ & $\mathbf{1 5}(\mathbf{3 9 . 4 7})$ & $3(7.89)$ & $5(13.16)$ & $4(10.53)$ & 38 \\
& Two-star & $\mathbf{3 1}(\mathbf{3 7 . 3 5})$ & $26(31.33)$ & $12(14.46)$ & $8(9.64)$ & $6(7.23)$ & 83 \\
Hotel & Three-star & $\mathbf{4 4 ( 5 5 . 0 0 )}$ & $23(28.75)$ & $4(5.00)$ & $7(8.75)$ & $2(2.50)$ & 80 \\
grade & Four-star & $\mathbf{7 6 ( 5 5 . 4 7 )}$ & $38(27.74)$ & $21(15.33)$ & $1(0.73)$ & $1(0.73)$ & 137 \\
& Five-star & $\mathbf{1 0 5 ( 6 8 . 6 3 )}$ & $37(24.18)$ & $5(3.27)$ & $4(2.61)$ & $2(1.31)$ & 153 \\
& Total & $267(54.38)$ & $139(28.31)$ & $45(9.16)$ & $25(5.09)$ & $15(3.05)$ & 491 \\
\hline
\end{tabular}

Table 7. Social media is about PR

\begin{tabular}{llllllll}
\hline & $\begin{array}{l}\text { Strongly } \\
\text { Agree }\end{array}$ & Agee & $\begin{array}{l}\text { Neither Agree } \\
\text { nor Disagree }\end{array}$ & Disagree & $\begin{array}{l}\text { Strongly } \\
\text { Disagree }\end{array}$ & Total \\
\hline & One-star & $12(31.6)$ & $\mathbf{2 0}(\mathbf{5 2 . 6 )}$ & $2(5.3)$ & $1(2.6)$ & $3(7.9)$ & 38 \\
& Two-star & $\mathbf{3 4 ( 4 1 )}$ & $27(32.5)$ & $12(14.5)$ & $6(7.2)$ & $4(4.8)$ & 83 \\
Hotel & Three-star & $\mathbf{4 3 ( 5 3 . 8 )}$ & $27(33.8)$ & $4(5.00)$ & $5(6.3)$ & $1(1.3)$ & 80 \\
grade & Four-star & $\mathbf{7 4 ( 5 4 . 0 )}$ & $40(29.2)$ & $21(15.3)$ & $1(0.7)$ & $1(0.7)$ & 137 \\
& Five-star & $\mathbf{1 0 4}(\mathbf{6 8 . 0})$ & $40(26.1)$ & $5(3.3)$ & $3(2.0)$ & $1(0.7)$ & 153 \\
& Total & $267(54.4)$ & $154(31.4)$ & $44(9.0)$ & $16(3.3)$ & $10(2.0)$ & 491 \\
\hline
\end{tabular}

Table 6 compares the perception that social media is about marketing and Table 7 compares the perception that social media is about PR. Most surveyed hotels strongly agreed that social media is about marketing, while 25 hotels (5.09\%) disagreed and 15 hotels (3.05\%) strongly disagreed (Table 8). In general, the proportion of hotels agreeing and strongly agreeing that social media is about marketing increased with increasing grades. Mostly, four-star hotels neither agreed nor disagreed with this statement (Table 6).

In Table 7, a similar trend is noted. Most respondents had the perception (54.4\% strongly agreed and 31.4\% agreed) that social media is about PR. Only 16 (3.3\%) disagreed and 10 (2.0\%) strongly disagreed. Of all the one-star hotels, $52.6 \%$ agreed that social media is about PR. Altogether $40.7 \%$ of the two-star, $53.8 \%$ of the three-star, $54 \%$ of the four-star, and $68 \%$ of the five-star hotels agreed that social media is about PR. In general, the proportion of hotels agreeing to this statement increased with an increasing grade of hotel. Thus, except one-star hotels, all hotels perceive that social media is about marketing and PR.

Table 8 reports the use of different social media across the three locations.

Table 8. Usage of different social media by location

\begin{tabular}{llllll}
\hline & & USA & UK & Egypt & Total \\
\hline \multirow{4}{*}{ Facebook } & Always & $164(33.4)$ & $158(32.2)$ & $164(33.4)$ & $\mathbf{4 8 6}(\mathbf{9 9 . 0})$ \\
& Sometimes & $4(0.8)$ & $1(0.2)$ & $0(0.0)$ & $5(1.0)$ \\
& Never & $0(0.0)$ & $0(0.0)$ & $0(0.0)$ & $0(0.0)$ \\
& Always & $159(32.4)$ & $144(29.3)$ & $150(30.5)$ & $\mathbf{4 5 3 ( 9 2 . 3 )}$ \\
Twitter & Sometimes & $9(1.8)$ & $15(3.1)$ & $13(2.6)$ & $37(7.5)$ \\
& Never & $0(0.0)$ & $0(0.0)$ & $1(0.2)$ & $1(0.2)$ \\
& Always & $10(2.0)$ & $4(0.8)$ & $1(0.2)$ & $15(3.1)$ \\
Bebo & Sometimes & $144(29.3)$ & $105(21.4)$ & $82(16.7)$ & $\mathbf{3 3 1 ( 6 7 . 4 )}$ \\
& Never & $14(2.9)$ & $50(10.2)$ & $81(16.5)$ & $145(29.5)$ \\
& Always & $80(16.3)$ & $138(28.1)$ & $149(30.3)$ & $\mathbf{3 6 7}(\mathbf{7 4 . 7})$ \\
& Sometimes & $82(16.7)$ & $16(3.3)$ & $14(2.9)$ & $112(22.8)$ \\
& Never & $6(1.2)$ & $5(1.0)$ & $1(0.2)$ & $12(2.4)$ \\
\hline
\end{tabular}




\begin{tabular}{|c|c|c|c|c|c|}
\hline & Always & 93 (18.9) & $136(27.7)$ & $144(29.3)$ & 373 (76.0) \\
\hline \multirow[t]{3}{*}{ YouTube } & Sometimes & 67 (13.6) & $18(3.7)$ & $18(3.7)$ & $103(21.0)$ \\
\hline & Never & $8(1.6)$ & $5(1.0)$ & $2(0.4)$ & $15(3.1)$ \\
\hline & Always & 87 (17.7) & $119(24.2)$ & $126(25.7)$ & 332 (67.6) \\
\hline \multirow[t]{3}{*}{ Flickr } & Sometimes & 75 (15.3) & $37(7.5)$ & $37(7.5)$ & 149 (30.3) \\
\hline & Never & $6(1.2)$ & $3(0.6)$ & $1(0.2)$ & $10(2.0)$ \\
\hline & Always & 78 (15.9) & $48(9.8)$ & $42(8.6)$ & $168(34.2)$ \\
\hline \multirow[t]{3}{*}{ Foursquares } & Sometimes & 72 (14.7) & $99(20.2)$ & 115 (23.4) & 286 (58.2) \\
\hline & Never & $18(3.7)$ & $12(2.4)$ & $7(1.4)$ & $37(7.5)$ \\
\hline & Always & $43(8.8)$ & $0(0.0)$ & $0(0.0)$ & $43(8.8)$ \\
\hline \multirow[t]{3}{*}{ Blogs } & Sometimes & $98(20.0)$ & 139 (28.3) & $141(28.7)$ & 378 (77.0) \\
\hline & Never & $27(5.5)$ & $20(4.1)$ & $23(4.7)$ & 70 (14.3) \\
\hline & Always & $64(13.0)$ & $44(9.0)$ & $38(7.7)$ & $146(29.7)$ \\
\hline \multirow[t]{2}{*}{ Others } & Sometimes & $44(9.0)$ & 65 (13.2) & $49(10.0)$ & $158(32.2)$ \\
\hline & Never & $60(12.2)$ & $50(10.2)$ & 77 (15.7) & $187(38.1)$ \\
\hline
\end{tabular}

Most hotels in all three locations use some sort of social media. Hotels mostly used Facebook (99\%), Twitter (92.3\%), blogs (77\%), and YouTube (76\%). This forms the basis of the analysis that since hotels use social media in general, they can be told about the benefits of using social media as a branding strategy, which would help them achieve higher occupancy rates and, therefore, earn higher revenues.

The usage of social media by location is depicted in Table 9 .

Table 9. Number of social media used by location

\begin{tabular}{llll}
\hline \multirow{2}{*}{ Social media use } & USA & UK & Egypt \\
\cline { 2 - 4 } & Frequency & Frequency & Frequency \\
\hline Sometimes and/or Never & $4(2.4)$ & $0(0.0)$ & $0(0.0)$ \\
used social media & $3(1.8)$ & $1(0.6)$ & $2(1.2)$ \\
1 & $\mathbf{4 3 ( 2 5 . 6 )}$ & $9(5.7)$ & $5(3.1)$ \\
2 & $10(6.0)$ & $10(6.3)$ & $11(6.7)$ \\
3 & $12(7.1)$ & $27(17.0)$ & $23(14.0)$ \\
4 & $35(20.8)$ & $48(30.2)$ & $\mathbf{6 3}(\mathbf{3 8 . 4})$ \\
5 & $20(11.9)$ & $\mathbf{5 4}(\mathbf{3 4 . 0})$ & $58(35.4)$ \\
6 & $18(10.7)$ & $10(6.3)$ & $2(1.2)$ \\
7 & $17(10.1)$ & $0(0.0)$ & $0(0.0)$ \\
8 & $6(3.6)$ & $0(0.0)$ & $0(0.0)$ \\
9 & $168(100.0)$ & $159(100.0)$ & $164(100.0)$ \\
Total & & & \\
\hline
\end{tabular}

Only $2.4 \%$ of hotels in the USA sometimes or never used any sort of social media. In the USA, $25.6 \%$ of hotels always used two social media platforms. In the UK, 64\%, and in Egypt, 38.4\% of hotels always used six and five social media platforms, respectively. However, $3.6 \%$ of hotels in the USA always used all nine social media platforms listed in the table. It can be concluded that hotels use some form of social media to communicate with potential customers and that it is common for hoteliers to use several social media sites at one time.

To determine the factors that motivate hoteliers to use social media as a branding strategy, a Logit model was developed. This was appropriate for this purpose, since the dependent variable was binary in nature. A set of independent variables were regressed on the dependent variable to identify the motivational factors for using social media. 
The descriptive statistics of the dependent variable is presented in Table 10 and the econometric model is presented in Table 11.

Table 10. Descriptive statistics of the dependent and independent variables

\begin{tabular}{|c|c|c|}
\hline Variable & Mean & Standard deviation \\
\hline Use social media as part of a branding strategy ( 1 = yes; otherwise 0$)$ & 0.59 & 0.49 \\
\hline $\begin{array}{l}\text { Three-star hotel with } 50-100 \text { rooms }(1=\text { if the hotel is a three-star and has } \\
50-100 \text { rooms; } 0 \text { otherwise) }\end{array}$ & 0.04 & 0.21 \\
\hline $\begin{array}{l}\text { Three-star hotel with more than } 100 \text { rooms ( } 1=\text { if the hotel is a three-star and } \\
\text { has more than } 100 \text { rooms; } 0 \text { otherwise) }\end{array}$ & 0.09 & 0.28 \\
\hline $\begin{array}{l}\text { Four-star hotel with } 50-100 \text { rooms }(1=\text { if the hotel is a four-star and has } \\
50-100 \text { rooms; } 0 \text { otherwise) }\end{array}$ & 0.09 & 0.29 \\
\hline $\begin{array}{l}\text { Four-star hotel with more than } 100 \text { rooms ( } 1=\text { if the hotel is a four-star and has } \\
\text { more than } 100 \text { rooms; } 0 \text { otherwise) }\end{array}$ & 0.14 & 0.35 \\
\hline $\begin{array}{l}\text { Five-star hotel with } 50-100 \text { rooms ( } 1 \text { = if the hotel is a five-star and has 50-100 } \\
\text { rooms; } 0 \text { otherwise) }\end{array}$ & 0.09 & 0.28 \\
\hline $\begin{array}{l}\text { Five-star hotel with more than } 100 \text { rooms ( } 1=\text { if the hotel is a five-star and has } \\
\text { more than } 100 \text { rooms; } 0 \text { otherwise) }\end{array}$ & 0.17 & 0.37 \\
\hline $\begin{array}{l}\text { Perception (= } 1 \text { if hoteliers have the perception that social media is about } \\
\text { marketing and PR; otherwise } 0 \text { ) }\end{array}$ & 0.83 & 0.38 \\
\hline USA ( $=1$ if the location of the hotel is in the USA; otherwise 0 ) & 0.34 & 0.47 \\
\hline UK (=1 if the location of the hotel is the UK; otherwise 0 ) & 0.32 & 0.47 \\
\hline
\end{tabular}

Table 11. Logit regression of the use of social media

\begin{tabular}{|c|c|c|c|c|c|}
\hline \multirow{2}{*}{$\begin{array}{l}\text { Variables } \\
\text { Three-star hotel with 50-100 rooms }\end{array}$} & \multirow{2}{*}{$\begin{array}{l}\text { Marginal } \\
0.185^{* *}\end{array}$} & \multirow{2}{*}{$\begin{array}{l}\mathbf{z} \\
2.3\end{array}$} & \multirow{2}{*}{$\begin{array}{l}\mathbf{p}>\mathbf{z} \\
0.021\end{array}$} & \multicolumn{2}{|c|}{ [95 \% Confidence Interval] } \\
\hline & & & & 0.027 & 0.343 \\
\hline $\begin{array}{l}\text { Three-star hotel with more than } 100 \\
\text { rooms }\end{array}$ & $0.156^{* *}$ & 2.25 & 0.024 & 0.020 & 0.291 \\
\hline Four-star hotel with 50-100 rooms & $0.308 * * *$ & 6.8 & 0.000 & 0.219 & 0.397 \\
\hline $\begin{array}{l}\text { Four-star hotel with more than } 100 \\
\text { rooms }\end{array}$ & $0.291^{* * *}$ & 6.31 & 0.000 & 0.201 & 0.381 \\
\hline Five-star hotel with 50-100 rooms & $0.414^{* * *}$ & 12.99 & 0.000 & 0.352 & 0.477 \\
\hline $\begin{array}{l}\text { Five-star hotel with more than } 100 \\
\text { rooms }\end{array}$ & $0.437 * * *$ & 12.32 & 0.000 & 0.367 & 0.506 \\
\hline Perception & $0.203^{* * *}$ & 2.94 & 0.003 & 0.068 & 0.338 \\
\hline USA & $0.234^{* * *}$ & 4.28 & 0.000 & 0.127 & 0.342 \\
\hline UK & $0.346 * * *$ & 6.67 & 0.000 & 0.245 & 0.448 \\
\hline $\begin{array}{l}\text { Number of observations }=491 \\
\text { LR chi2 }(9)=131.38 \\
\text { Prob }>\text { chi2 }=0.0000 \\
\text { Log likelihood }=-267.24977 \\
\text { Pseudo R2 }=0.1973\end{array}$ & & & & & \\
\hline
\end{tabular}

The dependent variable for the analysis was whether hoteliers used social media as part of their branding strategies. The value of the variable was one if hoteliers used social media as part of their branding strategies and zero otherwise. Altogether, $59 \%$ of hotels used social media as a branding strategy. 
The independent variables had three categories: (i) the first category included several variables on the number of rooms and hotel grade, (ii) the second category included a perception variable, and (iii) the last category included two variables with reference to the location of the hotel.

For number of rooms and hotel grade, six dummy variables were created: (i) three-star hotels with 50-100 rooms, (ii) three-star hotels with more than 100 rooms, (iii) four-star hotels with 50-100 rooms, (iv) four-star hotels with more than 100 rooms, (v) five-star hotels with 50-100 rooms, and (vi) five-star hotels with more than 100 rooms.

The value of the perception variable was one if hoteliers perceived that social media is about marketing and PR and zero otherwise. Altogether, $83 \%$ of hoteliers had such a perception.

For the location category, two dummy variables were generated, namely the USA and the UK. The variables had the value of one if the surveyed hotel was in the USA or the UK, and 0 otherwise. Altogether, $34 \%$ of hotels were in the USA, and 32\% were in the UK.

A Logit model was performed and the marginal effect of the independent variable on the dependent variable is reported in Table 11. All variables were found to be significant with the dependent variable at a $1 \%$ or lower level of significance, except three-star hotels with 50 to 100 rooms and three-star hotels with more than 100 rooms, which were significant at the $5 \%$ level of significance.

The probability of using social media as a branding strategy increased by $19 \%$ if hotels were graded three-stars and had between 50 to 100 rooms, whereas the probability increased by $16 \%$ if hotels were graded three-stars with had more than 100 rooms. For four-star hotels with 50 to 100 rooms, the probability of using social media increased by $31 \%$, and for hotels of the same grade with more than 100 rooms, the probability increased by $29 \%$. Hotels with a five-star grading and with 50 to 100 rooms had a $41 \%$ greater likelihood of using social media as a branding strategy, whereas five-star hotels with more than 100 rooms had a $43 \%$ greater likelihood of using social media.

From this, it can be concluded that hotels with a higher grading and with a larger number of rooms have a greater likelihood of using social media as a branding strategy compared with those that have a lower grade (one-star and two-star) with fewer rooms (fewer than 50).

Hoteliers that perceived that social media is about marketing and PR have a $20 \%$ greater likelihood of using social media as a branding strategy, which is self-explanatory. If a hotel is situated in the USA, the probability of using social media increases by $23 \%$, while the increase in probability of using social media for a hotel in the UK is $35 \%$. This indicates that compared with hotels in Egypt, hotels in the USA and UK have a greater likelihood of using social media. This can be explained by the greater access to the Internet and thus to social media sites.

\section{Conclusion}

Social media is crucial in this respect for providing customers with the personal touch they expect. Because social media is a good way to establish a relationship between hotels and their customers, it allows for one-to-one communication between them. Hotels can also receive regular feedback from their customers on their customer service, marketing campaigns, and most importantly, stay experiences. Therefore, hotels have a better chance of attracting customers by using social media and having good customer reviews compared with not using social media and/or having low customer reviews. Addressing negative reviews through social media sites also builds customer confidence.

Personal interaction through social media platforms such as Facebook or Twitter improves communication with existing and potential customers. More importantly, news about the hotel, such as the expansion of its facilities or special offers, can be easily disseminated to thousands or millions of customers with just a few clicks.

Hotels in the USA, the UK, and Egypt all use social media as part of their strategies. However, the pattern of usage is different by location for various factors. Exposure to the concept, access to the Internet, and the Internet usage infrastructure could be the main reasons for the disparity in social media usage. It is self-explanatory that people that have less exposure to a facility will use it less.

From the current study, it is apparent that hotels with higher grades (three-star, four-star, and five-star) and larger room capacities (more than 50 rooms) have a higher probability of using social media. Hotels in the USA and UK also have a higher usage of social media compared with those in Egypt. This perception also increases the likelihood of using social media. As a policy recommendation, the respective agencies should carry out campaigns to help Egyptian hoteliers perceive the benefits of social media and increase its usage among them. 


\section{References}

Aaker, D. (1991). Managing brand equity: Capitalizing on the value of a brand name. New York: Free Press.

Aaker, D. A. (2004). Leveraging the corporate brand. California Management Review, 46(3), 6-18.

Aaker, D. A., \& Jacobson, R. (2001). The value relevance of brand attitude in high technology markets. Journal of Marketing Research, 38(4), 485-493. http://dx.doi.org/10.1509/jmkr.38.4.485.18905

Aggarwal, A. (2009). Social Media Strategies for Hotels. Milestone Internet Marketing. Retrieved from http://www.hospitalitynet.org/news//4042853.html

Aggarwal, B. (2011). Social Media Marketing for Hotels. Retrieved from http://www.hotelindustryonline.com/industry-voices/37-social-media-marketing-for-hotels.html.

Bridges, S., O’Neill, K., \& Cromie, S. (2003). Understanding Enterprises: Entrepreneurship and Small Business. New York: Palgrave MacMillan.

Browser Media (2011). Social Media Statistics Show Huge Growth. Retrieved from http://www.browsermedia.co.uk/2011/03/30/2011-social-media-statistics-show-huge-growth/

Falkow, S. (2009). Social media strategy. E+ White paper, September 2009.

Gay, L. R., \& Airasian, P. (2000). Educational research: Competencies for analysis and application. Upper Saddle River, NJ: Prentice-Hall.

Ghali, P. (2011). Calculating your social media marketing return on investment - A how to guide for new social media marketers. Retrieved from http://www.icontact.com/static/pdf/Calculating_Social_Media_ROI.pdf

Grove, J. V. (2010). How Hospitality Companies are Using Social Media For Real Results. Retrieved from http://mashable.com/2010/05/24/hospitality-social-media/

Hasler, S. (2011). Use social media to promote your Hotel's website and get more reservations today. Retrieved from http://www.globres.com/content.php?page_id=1822

Hessinger, A., (2011). 10 Bright Ideas: Using Social Media for Your Small business. Bizsugar. Retrieved from http://www. bizsugar.com/blog/2011/02/01/10-bright-ideas-using-social-media-for-your-small-business/

Jiang, W., Dev, C., \& Rao, V. (2002). Brand extension and customer loyalty: Evidence from the lodging industry. The Cornell Hotel and Restaurant Administration Quarterly, 43(4), 5-16. http://dx.doi.org/10.1016/S0010-8804(02)80037-4

Jones, R. (2009). Social media marketing 101, Part 1. Retrieved from http://searchenginewatch.com/3632809 (July 23, 2010).

Kimes, S. E. (2000) Revenue management on the links. Cornell Hotel and Restaurant Administration Quarterly, 41(1), 120-127. http://dx.doi.org/10.1177/001088040004100129

Lacy, K. (2010). Hospitality Industry Changing With Social Media. Retrieved from http://kylelacy.com/hospitality-industry-changing-with-social-media/

Lanz, L., Fischoff, B., \& Lee, R. (2010). How Are Hotels Embracing Social Media in 2010? Examples of How to Begin Engaging. HVS online report, 1-29.

Malhotra, N. (2012). Basic marketing research (4th ed.). Upper Saddle River, NJ: Pearson.

Noone, B. M., McGuireb, K. A., \& Rohlfs, K. V. (2011). Social media meets hotel revenue management: Opportunities, issues and unanswered questions. Journal of Revenue and Pricing Management, 10, 293-305. http://dx.doi.org/10.1057/rpm.2011.12

O’Neil, J. W., \& Matilla, A. S. (2004). Hotel branding strategy: Its relationship to guest satisfaction and room revenue. Journal of hospitality and tourism research. http://dx.doi.org/10.1177/1096348004264081

O’Neill, J. W., \& Lloyd-Jones, A. R. (2001). Hotel values in the aftermath of September 11, 2001. The Cornell Hotel and Restaurant Administration Quarterly, 42(6), 10-21.

Okapara, F. O. (2007). The value of creativity and innovation in entrepreneurship. Journal of Asia Entrepreneurship and Sustainability, 3(2), 81-131.

Porter, M. E. (2008). The five competitive forces that shape strategy. Harvard Business Review, January, 1-18.

Rao, L. (2010). How Social Media Drives New Business: Six Case Studies. Tech Crunch. Retrieved from http://techcrunch.com/2010/07/17/how-social-media-drives-new-business-six-case-studies/ 
Saito, M. (2011). How Does Social Media Scale Personal Engagement? Retrieved from http:/coffeebeantech.com/en/blogs/social-business/219-how-does-social-media-scale-personal-engagement

Severn, B. (2010). Branding Your Image. Retrieved from http://fivelakesmedia.com/branding-your-image/

Shocker, S., Srivastava, R., \& Ruekert, R. (1994). Challenges and opportunities facing brand management: An introduction to the special issue. Journal of Marketing Research, 31, $149-158$. http://dx.doi.org/10.2307/3152190

Sun, L. (2011). The Core Competences and Strategic Management of Raffles - A Case Study of Singapore Hotel Industry. International Journal of Innovation, Management and Technology, 2(4), 270-273.

Weed, J. (2011). Hotels Turn to Social Media to Connect With Travelers. New York Times. Retrieved from http://www.nytimes.com/2011/04/19/business/19hotels.html

Whalen, A. (2010). Social Media for Hotel Brands - the why not just the how. Retrieved from http://www.ideahatching.com/2010/03/social-media-for-hotel-brands-the-why-not-just-the-how

Williams, R. (2009). What is social media marketing? Retrieved from http://orangejack.com/media/what-is-social-media-marketing.pdf 